\title{
Catalytic effect of buffers on the degradation of doripenem in aqueous solutions
}

\author{
Judyta Cielecka-Piontek • Anna Jelińska
}

Received: 6 July 2010/ Accepted: 29 September 2010/Published online: 22 October 2010

(C) The Author(s) 2010. This article is published with open access at Springerlink.com

\begin{abstract}
The catalytic effect of buffers (phosphate, acetate, borate, carbonate) on the degradation of doripenem in aqueous solutions was studied at $313 \mathrm{~K}$ in the $\mathrm{pH}$ range $0.82-11.56\left(\mu=0.50 \mathrm{~mol} \mathrm{~L}^{-1}\right)$ by an HPLC-UV method developed for kinetic studies of doripenem. It was observed that general acid-base catalysis occurred in all buffers and so catalytic rate constants were calculated. Specific acidbase catalysis of doripenem involved degradation of protonated molecules and zwitter ions of doripenem catalyzed by hydrogen ions, spontaneous degradation of zwitter ions under the influence of water and degradation of zwitter ions and monoanions catalyzed by hydroxide ions.
\end{abstract}

Keywords Doripenem - Catalytic effect of buffers - Catalytic rate constants · $\mathrm{pH}$-rate profile

\section{Introduction}

Doripenem (S-4661) is a new parenteral carbapenem (Fig. 1). Doripenem, similarly to meropenem, ertapenem and biapenem, contains a $1-\beta$-methyl group that prevents degradation caused by renal dehydropeptidase I and therefore does not need to be protected with an inhibitor of this enzyme [1,2]. Doripenem has a broad spectrum of antimicrobial activity, against both Gram-postitive and Gram-negative bacteria, including Pseudomonas aeruginosa [3-5].

Carbapenems are susceptible to degradation during storage and after preparation of parenteral solutions [6-11]. The catalytic effect of citrate, phosphate, acetate, borate and carbonate buffers on the degradation of imipenem has been studied [12].

J. Cielecka-Piontek $(\bowtie) \cdot$ A. Jelińska

Department of Pharmaceutical Chemistry, Faculty of Pharmacy, Poznan University of Medical Sciences, Grunwaldzka 6, 60-780 Poznań, Poland e-mail: jpiontek@ump.edu.pl 
Fig. 1 Chemical structure of doripenem<smiles>C[C@H](O)[C@H]1C(=O)N2C(C(=O)O)=C(S[C@@H]3CN[C@H](CNS(N)(=O)=O)C3)[C@H](C)[C@H]12</smiles>

The components of carbonate buffer do not demonstrate a catalytic effect on the degradation of ertapenem but it was observed that catalysis occurs in the presence of acetate, phosphate and borate buffers [13]. Specific acid-base catalysis of carbapenems involves: (a) hydrolysis of imipenem, meropenem and ertapenem catalyzed by hydrogen ion; (b) spontaneous hydrolysis independent of the charge of imipenem and meropenem or dependent on zwitter ions and dianions of ertapenem under the influence of water and (c) hydrolysis of imipenem, meropenem and ertapenem catalyzed by hydroxide ions [13-15].

The aim of this study was to analyze general and specific acid-base hydrolysis of doripenem in the $\mathrm{pH}$ range $0.82-11.56$, at $313 \mathrm{~K}$. To determine the reaction rate constants under the influence of buffers, an isocratic HPLC-UV method was used.

\section{Experimental}

Material and reagents

Doripenem for injection, DORIBAX ${ }^{\mathrm{TM}}$ (Janssen-Cilag International NV), is a white to slightly yellowish sterile crystalline powder. Injection vials contain $500 \mathrm{mg}$ of doripenem monohydrate as an anhydrous basis. The $\mathrm{pH}$ of the infusion solution is between 4.5 and 5.5. DORIBAX ${ }^{\mathrm{TM}}$ is formulated without any excipients.

Theophylline was used as an internal standard. All other chemicals and solvents were obtained from Merck KGaA (Germany) and were of analytical or highperformance liquid chromatographic grade. High-quality pure water was prepared by using the Millipore purification system (Millipore, Molsheim, France, model Exil SA 67120).

\section{Chromatographic conditions}

Chromatographic separation and quantitative determination were performed by using a high performance liquid chromatograph containing a Shimadzu pump, model LC6A, a UV-VIS detector SPD-6AV (Shimadzu), a Rheodyne 7120 with a $50 \mu \mathrm{L}$ loop. As the stationary phase, a Lichrospher RP-18, $5 \mu \mathrm{m}$ particle size, $250 \mathrm{~mm} \times 4 \mathrm{~mm}$ (Merck, Darmstadt, Germany) was used. The mobile phase consisted of 4 volumes of acetonitrile and 96 volumes of ammonium acetate, $12 \mathrm{mmol} \mathrm{L}^{-1}$. The flow rate of the mobile phase was $1.2 \mathrm{~mL} \mathrm{~min}^{-1}$ and the wavelength of the UV-vis detector was set at $298 \mathrm{~nm}$. The HPLC method has been evaluated and validated for the determination of doripenem and biapenem in stability studies [16]. In order to study the effect of 
buffers on the stability of doripenem, the selectivity was examined for degraded samples in buffers.

Kinetic procedures

The degradation of doripenem in aqueous solutions was studied at $313 \mathrm{~K}$ in hydrochloric acid ( $\mathrm{pH} 0.82-2.05$ ), phosphate ( $\mathrm{pH} 2.10-3.38$ and 6.36-7.77), acetate ( $\mathrm{pH} 4.23-6.04)$, borate $(\mathrm{pH} 7.95-10.49)$ and carbonate (11.27-11.56) buffers. The $\mathrm{pH}$ values of the solutions and those of the buffer standards used to calibrate the $\mathrm{pH}$-meter were measured at reaction temperatures. The $\mathrm{pH}$ values of the reaction solutions in $\mathrm{HCl}$ were calculated from the equation $\mathrm{pH}=-\log \gamma_{\mathrm{HCl}}[\mathrm{HCl}]$ [17]. The ionic strength of all solutions was adjusted to $0.5 \mathrm{~mol} \mathrm{~L}^{-1}$ with a solution of sodium chloride $\left(4 \mathrm{~mol} \mathrm{~L}{ }^{-1}\right)$.

Degradation was initiated by dissolving an accurately weighed $5.0 \mathrm{mg}$ of DORIBAX $^{\mathrm{TM}}$ in $25 \mathrm{~mL}$ of the solution equilibrated to $313 \mathrm{~K}$ in stopped flasks. At specified times, samples of the reaction solutions $(1.0 \mathrm{~mL})$ were collected and instantly cooled with a mixture of ice and water, neutralized with $0.8 \mathrm{ml}$ of $\mathrm{NaOH}$ solutions of suitable concentrations and assayed. To each sample, $1.0 \mathrm{~mL}$ of the internal standard (theophylline $0.1 \mathrm{mg} \mathrm{mL}^{-1}$ ) was added.

\section{Results and discussion}

The HPLC method with UV detection used in this study has been found suitable for the determination of doripenem and biapenem under the stress conditions of hydrolysis (acid and base), oxidation, photolysis and thermal degradation [16]. The literature reports the influence of solution $\mathrm{pH}$, temperature and concentration of meropenem, ertapenem and biapenem on the formation of their degradation of products $[6,7,18]$. In this study, the selectivity of this method for the determination of doripenem in the presence of degradation products formed in buffers was confirmed. In the chromatogram, the symmetrical peak of doripenem $\left(t_{R}=\right.$ $5.8 \mathrm{~min}$ ) was clearly separated from the peak the of degradation products which formed in the $\mathrm{pH}$ range $0.86-11.56$ (Fig. 2).

The degradation of doripenem in DORIBAX ${ }^{\mathrm{TM}}$ is a pseudo first-order reaction described by the following equation:

$$
\ln \left(\mathrm{P}_{\mathrm{D}} / \mathrm{P}_{\mathrm{IS}}\right)=\ln \left(\mathrm{P}_{\mathrm{D}} / \mathrm{P}_{\mathrm{IS}}\right)_{0}-\mathrm{k}_{\mathrm{obs}} \mathrm{t}
$$

$\mathrm{P}_{\mathrm{D}}$ and $\mathrm{P}_{\mathrm{IS}}$ are the areas of the peaks of doripenem and the internal standard, at time $\mathrm{t}=0$ and $\mathrm{t}$, respectively. The semi-logarithmic plots $\ln \left(\mathrm{P}_{\mathrm{D}} / \mathrm{P}_{\mathrm{IS}}\right)=\mathrm{f}(\mathrm{t})$ were linear and their slopes were equal to the rate constants of the reactions with the negative $\operatorname{sign}\left(-\mathrm{k}_{\mathrm{obs}}\right)$.

At a constant $\mathrm{pH}$, ionic strength $\left(0.50 \mathrm{~mol} \mathrm{~L}^{-1}\right)$ and temperature, the rate constant $\mathrm{k}_{\mathrm{obs}}$ for the degradation of doripenem increased linearly as the total concentrations of the acetate, phosphate, borate and carbonate buffers increased (Fig. 3). The observed rate constant is a sum of several catalytic rate constants 
Fig. 2 HPLC chromatograms of: solution of doripenem at $\mathrm{t}=0$ $\left(\mathrm{c}=7.50 \times 10^{-2} \mathrm{mg} / \mathrm{mL}\right)$; solution of doripenem and its degradation products in borate buffer ( $\mathrm{pH} 8.10)$ after incubation $7.5 \mathrm{~min}$ at $313 \mathrm{~K}$ ( $D$ doripenem, $P$ degradation product, $I S$ internal standard)
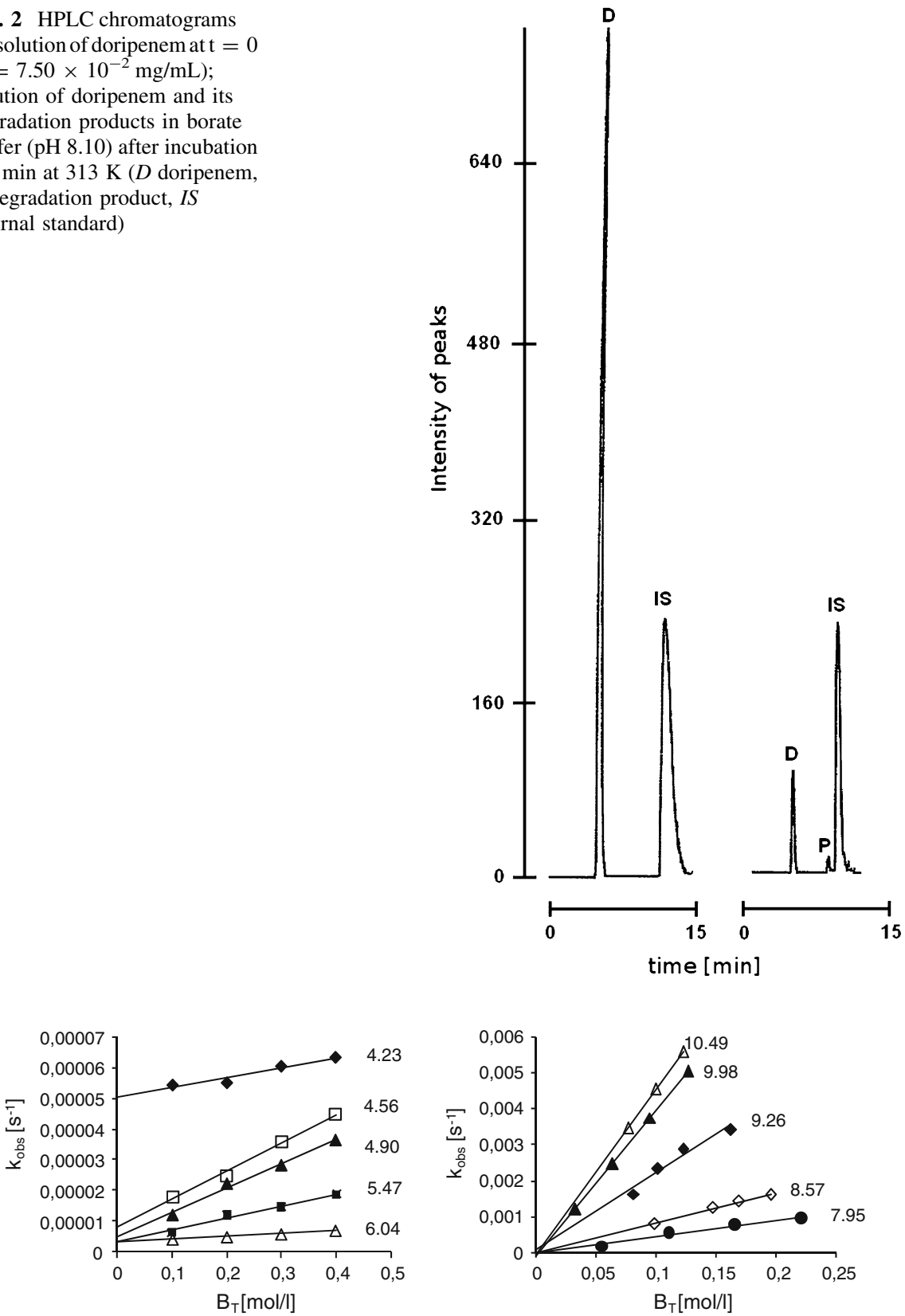

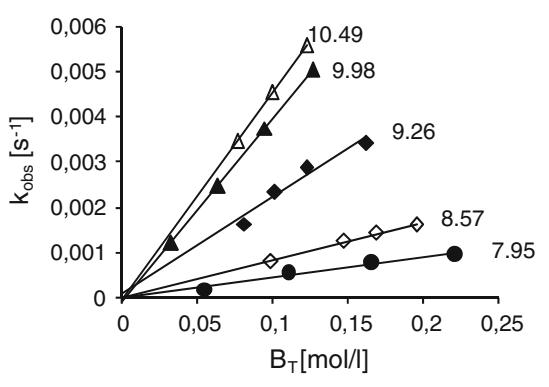

Fig. 3 Plots of $\mathrm{k}_{\mathrm{obs}}=\mathrm{f}\left(\mathrm{B}_{\mathrm{T}}\right)$ for the degradation of doripenem in acetate ( $\left.\mathrm{pH} 4.23-6.04\right)$ and in borate buffers (pH 7.95-10.49) at $313 \mathrm{~K}$

catalyzed by the buffer components and the rate constant at zero buffer concentration. Under the conditions of general acid-base catalysis, $\mathrm{k}_{\mathrm{obs}}$ was calculated from the following equation: 


$$
\mathrm{k}_{\mathrm{obs}}=\mathrm{k}_{\mathrm{pH}}+\mathrm{k}_{\mathrm{B}}\left[\mathrm{B}_{\mathrm{T}}\right]
$$

$\left[\mathrm{B}_{\mathrm{T}}\right]$ is the total buffer concentration, $\mathrm{k}_{\mathrm{pH}}$ the rate constant at zero buffer concentration, $\mathrm{k}_{\mathrm{B}}$ is the catalytic effect of the buffer components.

The catalytic effect of the acetate buffer was investigated at $\mathrm{pH} 4.23-6.04$. The observed rate constants were calculated from the following equation:

$$
\mathrm{k}_{\mathrm{obs}}=\mathrm{k}_{\mathrm{pH}}+\mathrm{k}_{\mathrm{AcH}}[\mathrm{AcH}]+\mathrm{k}_{\mathrm{AC}}-\left[\mathrm{Ac}^{-}\right]
$$

$\mathrm{AcH}$ is the undissociated acetic acid and $\mathrm{Ac}^{-}$is the acetate ion. The total acetate concentration $\mathrm{B}_{\mathrm{T}}$, is:

$$
\begin{gathered}
\mathrm{B}_{\mathrm{T}}=[\mathrm{AcH}]+\left[\mathrm{Ac}^{-}\right] \\
\mathrm{K}_{\mathrm{a}}=\frac{\left[\mathrm{H}^{+}\right]\left[\mathrm{Ac}^{-}\right]}{[\mathrm{AcH}]}
\end{gathered}
$$

The observed rate constant was calculated from the $\mathrm{pK}_{\mathrm{a}}$ of the acetic acid (4.52) and Eqs. 1 and 2.

$$
k_{o b s}=k_{p H}+B_{T} \frac{\mathrm{k}_{\mathrm{AcH}}\left[\mathrm{H}^{+}\right]+\mathrm{k}_{\mathrm{AC}} \mathrm{K}_{\mathrm{a}}}{\left[\mathrm{H}^{+}\right]+\mathrm{K}_{\mathrm{a}}}
$$

From the slopes of the plots $\mathrm{k}_{\mathrm{obs}} \mathrm{vs} f\left(\mathrm{~B}_{\mathrm{T}}\right)$ for each $\mathrm{pH}$, the buffer catalytic rate constants were calculated (Table 1). The buffer catalytic effect of phosphate $(\mathrm{pH}$ 2.10-3.38, $\mathrm{pK}_{\mathrm{a}}=2.10$ and $\mathrm{pH}$ 6.36-7.77, $\left.\mathrm{pK}_{\mathrm{a}}=6.58\right)$, borate $(\mathrm{pH} 7.95-10.49$, $\left.\mathrm{pK}_{\mathrm{a}}=8.90\right)$ and carbonate $\left(\mathrm{pH}=11.27-11.56, \mathrm{pK}_{\mathrm{a}}=10.02\right)$ buffers were calculated from the following equations:

$$
\begin{aligned}
& k_{o b s}=k_{p H}+B_{T} \frac{\mathrm{k}_{\mathrm{H}_{3} \mathrm{PO}_{4}}\left[\mathrm{H}^{+}\right]+\mathrm{k}_{\mathrm{H}_{2} P O_{4}^{-}} \mathrm{K}_{\mathrm{a}}}{\left[\mathrm{H}^{+}\right]+\mathrm{K}_{\mathrm{a}}} \\
& k_{o b s}=k_{p H}+B_{T} \frac{\mathrm{k}_{\mathrm{H}_{2} \mathrm{PO}_{4}^{-}}\left[\mathrm{H}^{+}\right]+\mathrm{k}_{\mathrm{HPO}_{4}^{2-}}}{\left[\mathrm{K}_{\mathrm{a}}^{+}\right]+\mathrm{K}_{\mathrm{a}}} \\
& k_{o b s}=k_{p H}+B_{T} \frac{\mathrm{k}_{\mathrm{H}_{3} \mathrm{BO}_{4}}\left[\mathrm{H}^{+}\right]+\mathrm{k}_{\mathrm{H}_{2} \mathrm{BO}_{3}^{-}} \mathrm{K}_{\mathrm{a}}}{\left[\mathrm{H}^{+}\right]+\mathrm{K}_{\mathrm{a}}} \\
& k_{o b s}=k_{p H}+B_{T} \frac{\mathrm{k}_{\mathrm{HCO}_{3}^{-}}\left[\mathrm{H}^{+}\right]+\mathrm{k}_{\mathrm{CO}_{3}^{2-}} \mathrm{K}_{\mathrm{a}}}{\left[\mathrm{H}^{+}\right]+\mathrm{K}_{\mathrm{a}}}
\end{aligned}
$$

From Eqs. 5-9, the $\mathrm{k}_{\mathrm{pH}}$ and the buffer catalytic rate constants of the phosphate, acetate, borate and carbonate buffer components were calculated (Table 1a).

The $\mathrm{k}_{\mathrm{pH}}$ rate constants determined in the buffer solutions and calculated from Eq. 1 under the conditions of general acid-base catalysis and in hydrochloric acid $\left(\mathrm{k}_{\mathrm{obs}}=\mathrm{k}_{\mathrm{pH}}\right)$ were used to calculate the relationship log $\mathrm{k}_{\mathrm{pH}}=\mathrm{f}(\mathrm{pH})$ (Table 2). The relationship $\log \mathrm{k}_{\mathrm{pH}}=\mathrm{f}(\mathrm{pH})$ indicates that in aqueous solutions of doripenem at $\mathrm{pH}$ 0.86-11.56 the following reactions occur:

- degradation of the protonated molecules and zwitter ions of doripenem catalyzed by hydrogen ions $\left(\mathrm{k}_{1}\right.$ and $\left.\mathrm{k}_{2}\right)$ 


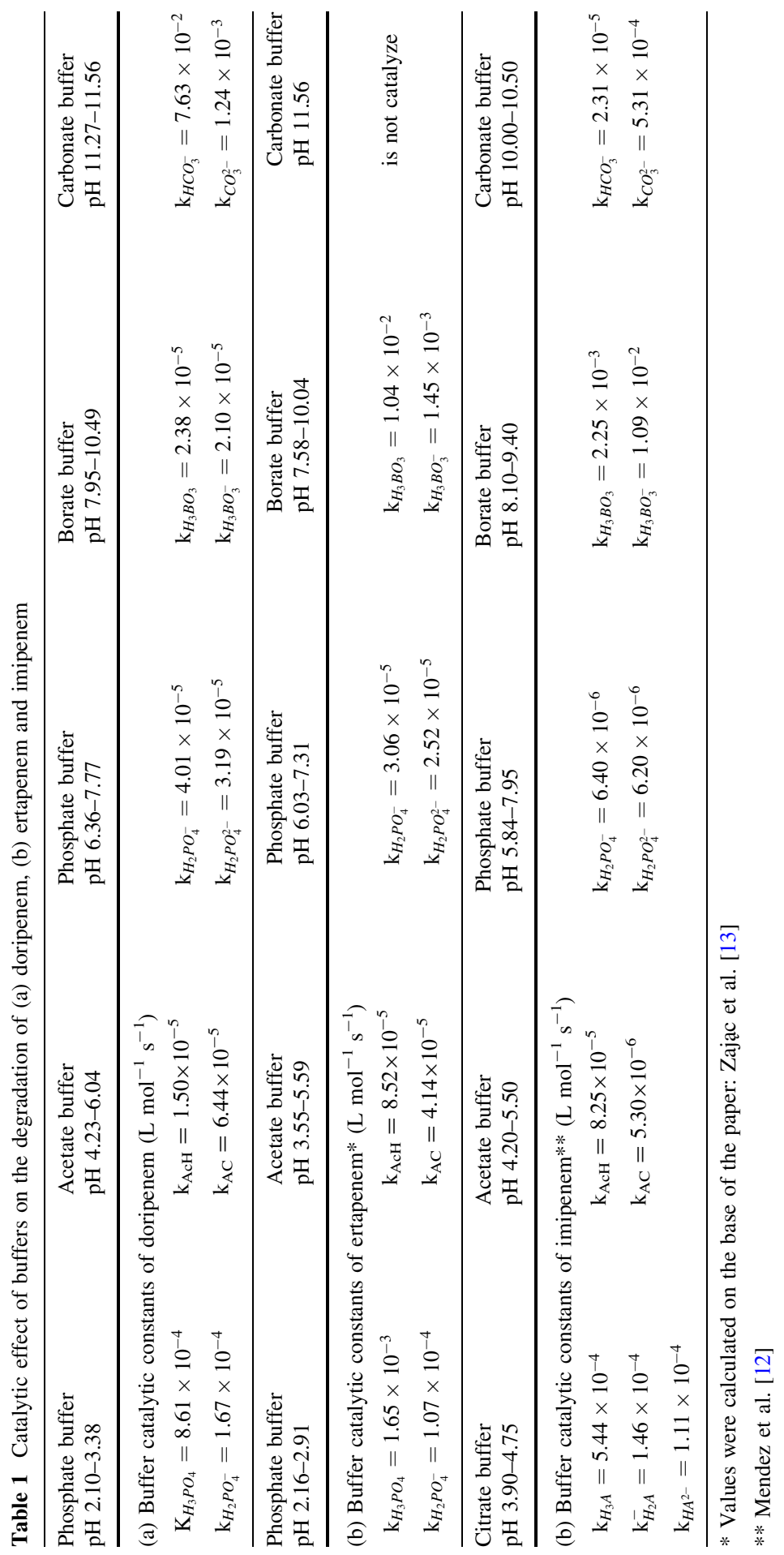


Table 2 Observed rate constants of degradation of doripenem in the $\mathrm{pH}$ range $0.82-11.56$ at $313 \mathrm{~K}$

\begin{tabular}{llll}
\hline $\mathrm{pH}$ & $\mathrm{k}_{\mathrm{obs}} \pm \Delta \mathrm{k}_{\mathrm{obs}}\left(\mathrm{s}^{-1}\right)$ & $\mathrm{pH}$ & $\mathrm{k}_{\mathrm{obs}} \pm \Delta \mathrm{k}_{\mathrm{obs}}\left(\mathrm{s}^{-1}\right)$ \\
\hline $\mathrm{HCl}$ & & & \\
0.82 & $(6.65 \pm 0.15) \times 10^{-3}$ & 1.38 & $(7.01 \pm 0.47) \times 10^{-4}$ \\
1.10 & $(2.09 \pm 0.11) \times 10^{-3}$ & 2.52 & $(2.52 \pm 0.27) \times 10^{-4}$ \\
\hline $\mathrm{B}_{\mathrm{T}}(\mathrm{mol} / \mathrm{L})$ & $\mathrm{k}_{\mathrm{obs}} \pm \Delta \mathrm{k}_{\mathrm{obs}}\left(\mathrm{s}^{-1}\right)$ & $\mathrm{k}_{\text {obs }} \pm \Delta \mathrm{k}_{\mathrm{obs}}\left(\mathrm{s}^{-1}\right)$ & $\mathrm{k}_{\mathrm{obs}} \pm \Delta \mathrm{k}_{\mathrm{obs}}\left(\mathrm{s}^{-1}\right)$ \\
& $\mathrm{pH} 2.10$ & $\mathrm{pH} 2.89$ & $\mathrm{pH} 3.38$ \\
\hline
\end{tabular}

Phosphate buffer, $\left[\mathrm{H}_{3} \mathrm{PO}_{4}\right]\left[\mathrm{KH}_{2} \mathrm{PO}_{4}\right]$

\begin{tabular}{llll}
0.40 & $(2.84 \pm 0.24) \times 10^{-4}$ & $(1.51 \pm 0.13) \times 10^{-4}$ & $(9.57 \pm 0.46) \times 10^{-5}$ \\
0.30 & $(2.55 \pm 0.22) \times 10^{-3}$ & $(1.25 \pm 0.09) \times 10^{-4}$ & $(7.02 \pm 2.29) \times 10^{-5}$ \\
0.20 & $(1.79 \pm 0.28) \times 10^{-4}$ & $(1.03 \pm 0.09) \times 10^{-4}$ & $(6.16 \pm 0.48) \times 10^{-5}$ \\
0.10 & $(1.38 \pm 0.14) \times 10^{-4}$ & $(7.02 \pm 0.71) \times 10^{-4}$ & \\
$\mathrm{k}_{\mathrm{pH}} \pm \Delta \mathrm{k}_{\mathrm{pH}}$ & $(8.55 \pm 3.08) \times 10^{-5}$ & $(4.62 \pm 1.09) \times 10^{-5}$ & $(2.47 \pm 1.51) \times 10^{-5 \mathrm{z}}$ \\
\hline $\mathrm{B}_{\mathrm{T}}(\mathrm{mol} / \mathrm{L})$ & $\mathrm{k}_{\text {obs }} \pm \Delta \mathrm{k}_{\mathrm{obs}}\left(\mathrm{s}^{-1}\right)$ & $\mathrm{k}_{\text {obs }} \pm \Delta \mathrm{k}_{\mathrm{obs}}\left(\mathrm{s}^{-1}\right)$ & $\mathrm{k}_{\mathrm{obs}} \pm \Delta \mathrm{k}_{\mathrm{obs}}\left(\mathrm{s}^{-1}\right)$ \\
& 4.23 & 4.56 & 4.90 \\
\hline
\end{tabular}

Acetate buffer, $\left[\mathrm{CH}_{3} \mathrm{COOH}\right]\left[\mathrm{CH}_{3 \mathrm{C}} \mathrm{COO}^{-}\right]$

\begin{tabular}{llll}
0.40 & $(2.75 \pm 0.42) \times 10^{-5}$ & $(1.95 \pm 0.58) \times 10^{-5}$ & $(1.58 \pm 1.71) \times 10^{-5}$ \\
0.30 & $(2.63 \pm 0.14) \times 10^{-5}$ & $(1.57 \pm 1.08) \times 10^{-5}$ & $(1.22 \pm 0.35) \times 10^{-5}$ \\
0.20 & $(2.40 \pm 0.14) \times 10^{-5}$ & $(1.08 \pm 0.76) \times 10^{-5}$ & $(9.69 \pm 5.15) \times 10^{-6}$ \\
0.10 & $(2.01 \pm 0.28) \times 10^{-5}$ & $(7.81 \pm 0.16) \times 10^{-6}$ & $(5.32 \pm 0.91) \times 10^{-6}$ \\
$\mathrm{k}_{\mathrm{pH}} \pm \Delta \mathrm{k}_{\mathrm{pH}}$ & $(1.73 \pm 0.38) \times 10^{-5}$ & $(3.46 \pm 1.54) \times 10^{-6}$ & $(2.27 \pm 1.50) \times 10^{-6 z}$ \\
\hline $\mathrm{B}_{\mathrm{T}}(\mathrm{mol} / \mathrm{L})$ & $\mathrm{k}_{\mathrm{obs}} \pm \Delta \mathrm{k}_{\mathrm{obs}}\left(\mathrm{s}^{-1}\right)$ & $\mathrm{k}_{\mathrm{obs}} \pm \Delta \mathrm{k}_{\mathrm{obs}}\left(\mathrm{s}^{-1}\right)$ \\
\hline 0.40 & 5.47 & 6.04 \\
0.30 & $(8.14 \pm 2.59) \times 10^{-6}$ & $(3.06 \pm 0.98) \times 10^{-6}$ \\
0.20 & $(6.39 \pm 1.71) \times 10^{-6}$ & $(2.56 \pm 0.18) \times 10^{-6}$ \\
0.10 & $(5.26 \pm 0.54) \times 10^{-6}$ & $(2.02 \pm 0.26) \times 10^{-6}$ \\
$\mathrm{k}_{\mathrm{pH}} \pm \Delta \mathrm{k}_{\mathrm{pH}}$ & $(2.84 \pm 0.95) \times 10^{-6}$ & $(1.83 \pm 0.20) \times 10^{-6}$ \\
\hline $\mathrm{B}_{\mathrm{T}}(\mathrm{mol} / \mathrm{L})$ & $(1.40 \pm 1.07) \times 10^{-6}$ & $\mathrm{k}_{\mathrm{obs}} \pm \Delta \mathrm{k}_{\mathrm{obs}}\left(\mathrm{s}^{-1}\right)$ \\
\hline
\end{tabular}

Phosphate buffer, $\left[\mathrm{H}_{2} \mathrm{PO}_{4}^{-}\right]\left[\mathrm{HPO}_{4}^{-}\right]$

\begin{tabular}{llll}
0.40 & $(1.57 \pm 1.41) \times 10^{-6}$ & 0.30 & $(1.31 \pm 0,97) \times 10^{-5}$ \\
0.30 & $(1.23 \pm 1.40) \times 10^{-6}$ & 0.25 & $(1.14 \pm 0.98) \times 10^{-6}$ \\
0.20 & $(8.70 \pm 1.04) \times 10^{-7}$ & 0.20 & $(1.01 \pm 1.00) \times 10^{-5}$ \\
0.10 & $(6.40 \pm 1.39) \times 10^{-7}$ & 0.10 & $(6.01 \pm 12.3) \times 10^{-6}$ \\
$\mathrm{k}_{\mathrm{pH}} \pm \Delta \mathrm{k}_{\mathrm{pH}}$ & $(2.90 \pm 0.35) \times 10^{-6}$ & & $(2.66 \pm 0.43) \times 10^{-6}$ \\
\hline $\mathrm{B}_{\mathrm{T}}(\mathrm{mol} / \mathrm{L})$ & $\mathrm{k}_{\text {obs }} \pm \Delta \mathrm{k}_{\mathrm{obs}}\left(\mathrm{s}^{-1}\right)$ & $\mathrm{B}_{\mathrm{T}}(\mathrm{mol} / \mathrm{L})$ & $\mathrm{k}_{\text {obs }} \pm \Delta \mathrm{k}_{\text {obs }}\left(\mathrm{s}^{-1}\right)$ \\
& $\mathrm{pH} 7.19$ & $\mathrm{pH} 7.77$ \\
\hline
\end{tabular}

Phosphate buffer, $\left[\mathrm{H}_{2} \mathrm{PO}_{4}^{-}\right]\left[\mathrm{HPO}_{4}^{-}\right]$

\begin{tabular}{llll}
0.25 & $(1.15 \pm 0.39) \times 10^{-5}$ & 0.20 & $(1.30 \pm 1.77) \times 10^{-5}$ \\
\hline
\end{tabular}


Table 2 continued

\begin{tabular}{|c|c|c|c|}
\hline $\mathrm{B}_{\mathrm{T}}(\mathrm{mol} / \mathrm{L})$ & $\begin{array}{l}\mathrm{k}_{\mathrm{obs}} \pm \Delta \mathrm{k}_{\mathrm{obs}}\left(\mathrm{s}^{-1}\right) \\
\mathrm{pH} 7.19\end{array}$ & $\mathrm{~B}_{\mathrm{T}}(\mathrm{mol} / \mathrm{L})$ & $\begin{array}{l}\mathrm{k}_{\mathrm{obs}} \pm \Delta \mathrm{k}_{\mathrm{obs}}\left(\mathrm{s}^{-1}\right) \\
\mathrm{pH} 7.77\end{array}$ \\
\hline 0.20 & $(1.03 \pm 0.42) \times 10^{-5}$ & 0.15 & $(1.22 \pm 1.47) \times 10^{-5}$ \\
\hline 0.15 & $(7.67 \pm 1.60) \times 10^{-6}$ & 0.10 & $(8.54 \pm 2.49) \times 10^{-6}$ \\
\hline 0.10 & $(6.79 \pm 0.64) \times 10^{-6}$ & 0.05 & $(6.52 \pm 2.41) \times 10^{-6}$ \\
\hline $\mathrm{k}_{\mathrm{pH}} \pm \Delta \mathrm{k}_{\mathrm{pH}}$ & $(3.20 \pm 0.85) \times 10^{-6}$ & & $(4.29 \pm 1.00) \times 10^{-6}$ \\
\hline $\mathrm{B}_{\mathrm{T}}(\mathrm{mol} / \mathrm{L})$ & $\begin{array}{l}\mathrm{k}_{\mathrm{obs}} \pm \Delta \mathrm{k}_{\mathrm{obs}}\left(\mathrm{s}^{-1}\right) \\
\mathrm{pH} 7.96\end{array}$ & $\mathrm{~B}_{\mathrm{T}}(\mathrm{mol} / \mathrm{L})$ & $\begin{array}{l}\mathrm{k}_{\mathrm{obs}} \pm \Delta \mathrm{k}_{\mathrm{obs}}\left(\mathrm{s}^{-1}\right) \\
\mathrm{pH} 8.57\end{array}$ \\
\hline \multicolumn{4}{|c|}{ Borate buffer, $\left[\mathrm{NaBO}_{2}\right]\left[\mathrm{H}_{3} \mathrm{BO}_{3}\right]$} \\
\hline 0.221 & $(9.49 \pm 1.61) \times 10^{-4}$ & 0.195 & $(1.61 \pm 0.76) \times 10^{-3}$ \\
\hline 0.166 & $(7.54 \pm 0.39) \times 10^{-4}$ & 0.169 & $(1.43 \pm 0.12) \times 10^{-3}$ \\
\hline 0.110 & $(5.46 \pm 0.47) \times 10^{-4}$ & 0.147 & $(1.26 \pm 0.20) \times 10^{-3}$ \\
\hline 0.055 & $(2.06 \pm 0.39) \times 10^{-4}$ & 0.098 & $(8.09 \pm 0.37) \times 10^{-4}$ \\
\hline $\mathrm{k}_{\mathrm{pH}} \pm \Delta \mathrm{k}_{\mathrm{pH}}$ & $(6.81 \pm 0.6) \times 10^{-6}$ & & $(9.88 \pm 6.37) \times 10^{-6}$ \\
\hline $\mathrm{B}_{\mathrm{T}}(\mathrm{mol} / \mathrm{L})$ & $\begin{array}{l}\mathrm{k}_{\mathrm{obs}} \pm \Delta \mathrm{k}_{\mathrm{obs}}\left(\mathrm{s}^{-1}\right) \\
\mathrm{pH} 9.26\end{array}$ & $\mathrm{~B}_{\mathrm{T}}(\mathrm{mol} / \mathrm{L})$ & $\begin{array}{l}\mathrm{k}_{\mathrm{obs}} \pm \Delta \mathrm{k}_{\mathrm{obs}}\left(\mathrm{s}^{-1}\right) \\
\mathrm{pH} 10.49\end{array}$ \\
\hline 0.162 & $(3.43 \pm 0.27) \times 10^{-3}$ & 0.122 & $(6.02 \pm 0.67) \times 10^{-3}$ \\
\hline 0.122 & $(2.89 \pm 0.51) \times 10^{-3}$ & 0.099 & $(4.55 \pm 0.45) \times 10^{-3}$ \\
\hline 0.147 & $(2.35 \pm 0.17) \times 10^{-3}$ & 0.076 & $(3.48 \pm 0.51) \times 10^{-3}$ \\
\hline 0.098 & $(8.09 \pm 1.02) \times 10^{-4}$ & & \\
\hline $\mathrm{k}_{\mathrm{pH}} \pm \Delta \mathrm{k}_{\mathrm{pH}}$ & $(7.62 \pm 4.10) \times 10^{-5}$ & & $(7.80 \pm 4.47) \times 10^{-4}$ \\
\hline $\mathrm{B}_{\mathrm{T}}(\mathrm{mol} / \mathrm{L})$ & $\begin{array}{l}\mathrm{k}_{\mathrm{obs}} \pm \Delta \mathrm{k}_{\mathrm{obs}}\left(\mathrm{s}^{-1}\right) \\
\mathrm{pH} 11.27\end{array}$ & $\mathrm{~B}_{\mathrm{T}}(\mathrm{mol} / \mathrm{L})$ & $\begin{array}{l}\mathrm{k}_{\mathrm{obs}} \pm \Delta \mathrm{k}_{\mathrm{obs}}\left(\mathrm{s}^{-1}\right) \\
\mathrm{pH} 11.56\end{array}$ \\
\hline
\end{tabular}

\begin{tabular}{llll}
\multicolumn{2}{c}{ Carbonate buffer, $\left[\mathrm{Na}_{2} \mathrm{CO}_{3}\right]\left[\mathrm{NaHCO}_{3}\right]$} & & \\
0.095 & $(9.73 \pm 7.11) \times 10^{-4}$ & 0.095 & $(5.85 \pm 0.41) \times 10^{-3}$ \\
0.090 & $(9.54 \pm 6.13) \times 10^{-4}$ & 0.090 & $(5.79 \pm 0.12) \times 10^{-3}$ \\
0.075 & $(8.72 \pm 0.86) \times 10^{-4}$ & 0.075 & $(5.61 \pm 0.17) \times 10^{-3}$ \\
0.060 & $(8.07 \pm 5.11) \times 10^{-4}$ & 0.060 & $(5.45 \pm 0.72) \times 10^{-3}$ \\
$\mathrm{k}_{\mathrm{pH}} \pm \Delta \mathrm{k}_{\mathrm{pH}}$ & $(3.92 \pm 0.41) \times 10^{-3}$ & & $(4.76 \pm 0.18) \times 10^{-3}$ \\
\hline
\end{tabular}

- spontaneous hydrolysis of zwitter ions of doripenem under the influence of water $\left(\mathrm{k}_{3}\right)$

- degradation of zwitter ions and monoanions of doripenem catalyzed by hydroxide ions $\left(\mathrm{k}_{4}\right.$ and $\left.\mathrm{k}_{5}\right)$

The total rate of the reaction is equal to the sum of the partial reaction rates:

$$
\mathrm{k}_{\mathrm{pH}}=\left(\mathrm{k}_{1} \times \mathrm{f}_{1}+\mathrm{k}_{2} \times \mathrm{f}_{2}\right) \times \mathrm{a}_{\mathrm{H}^{+}}+\mathrm{k}_{3} \times \mathrm{f}_{2}+\mathrm{k}_{4} \times \mathrm{f}_{2} \times \mathrm{a}_{\mathrm{OH}^{-}}+\mathrm{k}_{5} \times \mathrm{a}_{\mathrm{OH}^{-}} \times \mathrm{f}_{3}
$$

where $a_{H^{+}}$and $a_{O_{H}}$ are the hydrogen and hydroxide ion activity, $f_{1}-f_{3}$ are the fractions of protonated molecules, zwitter ions and monoanions of doripenem. The 
$\mathrm{f}_{1}-\mathrm{f}_{3}$ values were calculated by using the values of $\mathrm{pK}_{\mathrm{a}}$ of doripenem that were 3.5 and 7.3 at $313 \mathrm{~K}$.

The partial reaction rates $\left(\mathrm{k}_{1}\right.$ and $\left.\mathrm{k}_{2}\right)$ were calculated by using the values of $\mathrm{k}_{\mathrm{pH}}$ from the $\mathrm{pH}$ range 1.10-4.56. In this $\mathrm{pH}$ range $\mathrm{f}_{1}+\mathrm{f}_{2}=1$. The plot $\mathrm{k}_{\mathrm{pH}} / \mathrm{a}_{\mathrm{H}^{+}}=$ $\mathrm{f}\left(\mathrm{f}_{2}\right)$ is linear. The partial reaction rates $\mathrm{k}_{1}\left(1.66 \times 10^{-2} \mathrm{~L} \mathrm{~mol}^{-1} \mathrm{~s}^{1}\right)$ and $\mathrm{k}_{2}$ $\left(1.31 \times 10^{-1} \mathrm{~L} \mathrm{~mol}^{-1} \mathrm{~s}^{-1}\right)$ are equal to the values of $\mathrm{k}_{\mathrm{pH}} / \mathrm{a}_{\mathrm{H}^{+}}$for $\mathrm{f}_{2}=0$ and $\mathrm{f}_{2}=1$, respectively. The partial reaction rates $\mathrm{k}_{4}$ and $\mathrm{k}_{5}$, were calculated by using the values of $\mathrm{k}_{\mathrm{pH}}$ from the $\mathrm{pH}$ range 7.19-11.56. In this $\mathrm{pH}$ range, $\mathrm{f}_{2}+\mathrm{f}_{3}=1$. The $\mathrm{k}_{\mathrm{pH}} / \mathrm{a}_{\mathrm{OH}^{-}}=\mathrm{f}\left(\mathrm{f}_{2}\right)$ plot is linear. The reaction rate $\mathrm{k}_{4}\left(11.64 \mathrm{~L} \mathrm{~mol}^{-1} \mathrm{~s}^{-1}\right)$ is equal to the value of $\mathrm{k}_{\mathrm{pH}} / \mathrm{a}_{\mathrm{OH}^{-}}$for $\mathrm{f}_{2}=1$, while $\mathrm{k}_{5}\left(8.33 \times 10^{-1} \mathrm{~L} \mathrm{~mol}^{-1} \mathrm{~s}^{-1}\right)$ is equal to the value of $\mathrm{k}_{\mathrm{pH}} / \mathrm{aOH}^{-}$for $\mathrm{f}_{2}=0$.

The mean value of the partial reaction rate $\left(\mathrm{k}_{3}=7.87 \times 10^{-7} \mathrm{~s}^{-1}\right)$ was calculated from Eq. 10 by using the $\mathrm{k}_{\mathrm{pH}}$ values of $\mathrm{k}_{\mathrm{pH}}$ from the $\mathrm{pH}$ range 4.90-6.04:

$$
\begin{aligned}
\mathrm{k}_{\mathrm{pH}}^{\prime}= & {\left[\mathrm{k}_{\mathrm{pH}}-\left(\mathrm{k}_{1} \times \mathrm{a}_{\mathrm{H}^{+}} \times \mathrm{f}_{1}+\mathrm{k}_{2} \times \mathrm{a}_{\mathrm{H}^{+}} \times \mathrm{f}_{2}+\mathrm{k}_{4} \times \mathrm{f}_{2} \times \mathrm{a}_{\mathrm{OH}^{-}}+\mathrm{k}_{5} \times \mathrm{a}_{\mathrm{OH}^{-}}\right.\right.} \\
& \left.\left.\times \mathrm{f}_{3}\right)\right] / \mathrm{f}_{2}
\end{aligned}
$$

The correct choice of Eq. 10 was verified by comparing the calculated theoretical profile of $\log \mathrm{k}_{\mathrm{pH}}=\mathrm{f}(\mathrm{pH})$ and the experimental results (Fig. 4).

The $\mathrm{pH}$-rate profiles of imipenem, ertapenem and doripenem demonstrate that they are the most stable in the $\mathrm{pH}$ range 6-7. This is the $\mathrm{pH}$ range where the spontaneous hydrolysis of the neutral and ionic molecules of carbapenem occurs. The influence of the catalytic effect of the components of phosphate and acetate buffers on the degradation of these carbapenems is similar. The components of a borate buffer have the greatest catalytic effect on the degradation of imipenem and ertapenem. A comparison of the values of the catalytic rate constants of a carbonate buffer shows that its components have a slight catalytic effect on the degradation of imipenem and do not catalyze the degradation of ertapenem (Table 1b). Therefore, the components of a carbonate buffer can be used in preparations of carbapenems as excipients, e.g. hydrocarbonate sodium in INVANZ and TIENAM and carbonate sodium in MERREM, MERONEM. Doripenem is susceptible to degradation under the influence of the components of common buffers. For that reason, no excipients are present in DORIBAX ${ }^{\mathrm{TM}}$.

\section{Conclusions}

Doripenem is susceptible to degradation catalyzed by the components of common buffers. Therefore DORIBAX ${ }^{\mathrm{TM}}$ contains doripenem without any excipients. The specific acid-base catalysis of doripenem involves: (a) degradation of the protonated molecules and zwitter ions of doripenem catalyzed by hydrogen ions, (b) spontaneous degradation of zwitter ions under the influence of water, (c) degradation of zwitter ions and monoanions catalyzed by hydroxide ions. Doripenem demonstrates the greatest stability at approximately $\mathrm{pH}$ 6.0. 
Fig. 4 pH-rate profile for the degradation of doripenem at $313 \mathrm{~K}$. The points are determined experimentally. The lines were calculated from Eq. 10

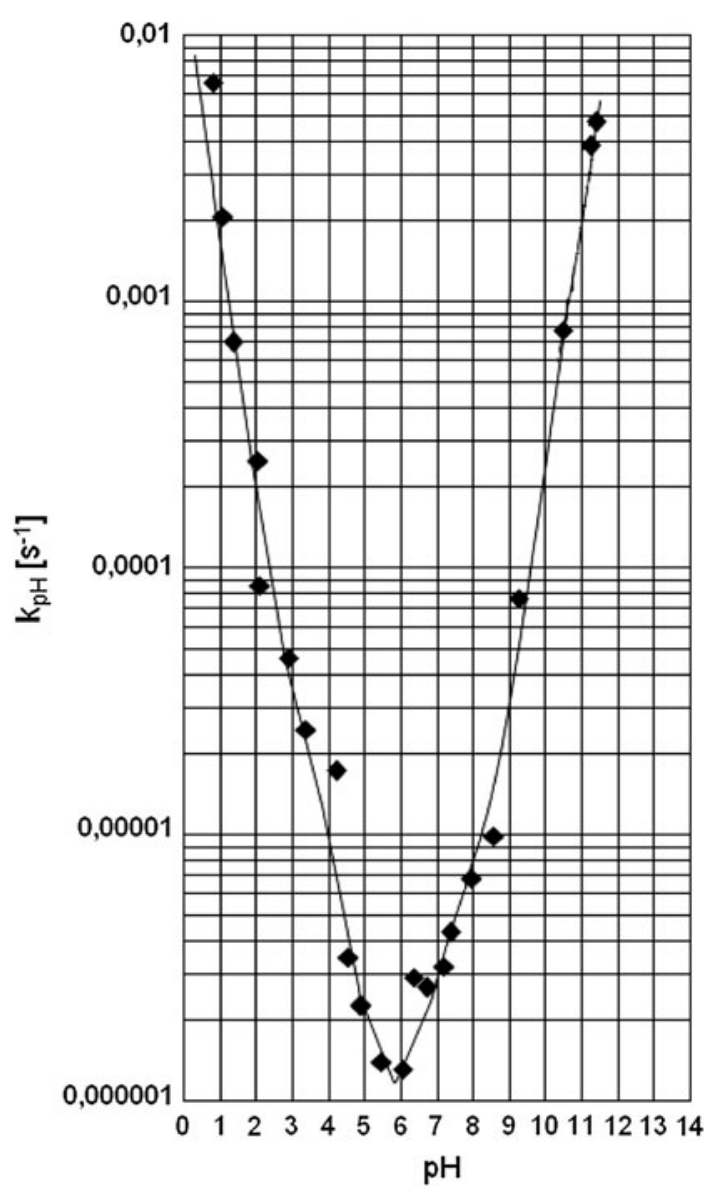

Acknowledgment This study was supported by a grant from the State Committee for Scientific Research, Poland (no. N N405 683040).

Open Access This article is distributed under the terms of the Creative Commons Attribution Noncommercial License which permits any noncommercial use, distribution, and reproduction in any medium, provided the original author(s) and source are credited.

\section{References}

1. Walsh F (2007) Doripenem: a new carbapenem antibiotic a review of comparative antimicrobial and bactericidal activities. Ther Clin Risk Manag 3:789-794

2. Livermore DM (2009) Doripenem: antimicrobial profile and clinical potential. Diag Microbiol Infect Dis 63:455-458

3. Goldstein EJ, Citron DM (2009) Activity of a novel carbapenem, doripenem, against anaerobic pathogens. Diagn Microbiol Infect Dis 63:447-454

4. Psathas PA, Kuzmission K, Ikeda SY (2008) Stability of doripenem in vitro in representative infusion solutions and infusion bags. Clin Ther 30:2075-2087 
5. Snydman DR, Jacobus NV, McDermott LA (2008) In vitro activities of doripenem, a new broadspectrum carbapenem, against recently collected clinical anaerobic isolates, with emphasis on the Bacteroides fragilis group. Antimicrob Agents Chemother 52:4492-4496

6. Xia M, Hang TJ, Zhang F, Li XM, Xu XY (2009) The stability of biapenem and structural identification of impurities in aqueous solution. J Pharm Biomed Anal 49:937-944

7. Elragehy NA, Abdel-Moety EM, Hassan NY, Rezk MR (2009) Stability-indicating determination of meropenem in presence of its degradation product. Talanta 77:28-36

8. Patel J, Piyush R, Cook SE (1997) Stability of meropenem in intravenous solutions. Am J Health-syst Pharm 57:412-421

9. Cielecka-Piontek J, Zając M, Jelińska A (2008) A comparison of the stability of ertapenem and meropenem in pharmaceutical preparations in solid state. J Pharm Biomed Anal 46:52-57

10. Mendez A, Dalomo J, Steppe M, Schapoval E (2006) Stability and degradation kinetics of meropenem in powder for injection and reconstituted sample. J Pharm Biomed Anal 41:1363-1366

11. Takeuchi Y, Takebayashi Y, Sunagawa M, Isobe Y, Hamazume Y, Uemura A, Noguchi Y (1994) The stability of a novel carbapenem antibiotic, Meropenem (SM-7338), in a solid state formulation for injection. Chem Pharm Bull 41:1998-2002

12. Mendez R, Alemany T, Villacorta JM (1991) Catalytic effect of buffers on degradation of imipenem (N-formimidoylthienamycin) in aqueous solution. Chem Pharm Bull 39:1998-2002

13. Zając M, Cielecka-Piontek J, Jelińska A (2007) Stability of ertapenem in aqueous solutions. J Pharm Biomed Anal 43:445-449

14. Takeuchi Y, Sunagawa M, Isobe Y, Hamazume Y, Noguchi T (1994) Stability of a 1-beta-metylcarbapenem antibiotic, meropenem in aqueous solutions. Chem Pharm Bull 43:689-692

15. Smith GB, Dezeny GC, Douglas A (1990) Stability and kinetics of degradation of imipenem in aqueous solution. J Pharm Sci 79:732-738

16. Cielecka-Piontek J, Jelińska A, Dołhań A, Nasreen Afroz Sh (2010) Progress in evaluation of quality of substances and pharmaceutical preparations (Poland). Poznan University of Medical, Poznan

17. Pawełczyk E, Hermann T (1982) The Fundamentals of stability drugs (Poland), PZWL, Warsaw

18. Sajonz P, Natishan TK, Wu Y, Williams JM, Pipik B, DiMichele L, Novak T, Pitzenberger S, Dubost D, Almarsson O (2001) Preparation, isolation, and characterization of dimeric degradation products of the 1 $\beta$-methylcarbapenem antibiotic, ertapenem. J Liq Chrom \& Rel Technol 24(19):2999-3015 